\title{
Community-Based Interventions in Prepared-Food Sources: A Systematic Review
}

\author{
Joel Gittelsohn, PhD; Seung Hee Lee-Kwan, PhD; Benjamin Batorsky, MPH \\ Suggested citation for this article: Gittelsohn J, Lee-Kwan SH, Batorsky B. Community-Based Interventions in Prepared-
} Food Sources: A Systematic Review. Prev Chronic Dis 2013;10:130073. DOI: http://dx.doi.org/10.5888/pcd10.130073 国 .

PEER REVIEWED

\section{Abstract}

\section{Introduction}

Food purchased from prepared-food sources has become a major part of the American diet and is linked to increased rates of chronic disease. Many interventions targeting prepared-food sources have been initiated with the goal of promoting healthful options. The objective of this study was to provide a systematic review of interventions in preparedfood sources in community settings.

\section{Methods}

We used PubMed and Google Scholar and identified 13 interventions that met these criteria: 1) focused on prepared-food sources in public community settings, 2) used an impact evaluation, 3) had written documentation, and 4) took place after 1990. We conducted interviews with intervention staff to obtain additional information. Reviewers extracted and reported data in table format to ensure comparability.

\section{Results}

Interventions mostly targeted an urban population, predominantly white, in a range of income levels. The most common framework used was social marketing theory. Most interventions used a nonexperimental design. All made use of signage and menu labeling to promote healthful food options. Several promoted more healthful cooking methods; only one introduced new healthful menu options. Levels of feasibility and sustainability were high; sales results showed increased purchasing of healthful options. Measures among consumers were limited but in many cases showed improved awareness and frequency of purchase of promoted foods.

\section{Conclusion}

Interventions in prepared-food sources show initial promising results at the store level. Future studies should focus on improved study designs, expanding intervention strategies beyond signage and assessing impact among consumers.

\section{Introduction}

Obesity is a multifactorial disease that has many contributing factors, including the food environment. Food environments in which energy-dense prepared foods (ready-to-eat foods that can be eaten outside the home or brought back or delivered to the home to eat) are readily available are associated with the increasing prevalence of obesity (1-3). As a consequence, environmental interventions may be more cost-effective, sustainable, and successful at reaching a large population than individual interventions (4). Today, Americans spend about half of their food dollars eating out $(5,6)$ compared with $25 \%$ in 1955 (7). Americans are expected to spend \$660.5 billion in 2013 on eating out, a 15-fold increase from 1970 (adjusted to current dollars) (7). The total energy intake per capita increased on average by $570 \mathrm{kcal}$ between 1977-78 and 2003-06; this increase has been attributed to greater portion sizes and a greater frequency of eating out (8). Although prepared foods are generally more costly than foods prepared at home, people who have low incomes consume them at high rates (9-11). Prepared-food sources may be an important venue for efforts to reduce obesity and risks for other chronic diseases. In the past several decades, multiple interventions were conducted in venues that provide prepared foods. One review (12) showed that interventions had success in private prepared-food-source environments, such as worksite and college cafeterias. However, no systematic reviews examined prepared-food source interventions in public community settings such as carryout, fast-food, and sit-down restaurants, even though preparedfood sources are more numerous in public settings than in private settings, and low-income individuals may have little 
access to private settings, which may offer more healthful options. The objective of this study was to systematically review community-based interventions in prepared-food sources that aimed to increase access to and consumption of healthful foods.

\section{Methods}

This systematic review was designed to identify interventions in public prepared-food sources; to present data on strategy, study design, evaluation, process indicators, and impact for each intervention identified; and to suggest next steps in research, practice, and policy. We followed the Preferred Reporting Items for Systematic Reviews and MetaAnalyses (PRISMA) guidelines, which provide 27 checklist items that aim to standardize the structure of meta-analyses and ensure comprehensive reporting (13).

\section{Data sources}

From September 2011 through January 2013, we used PubMed and Google Scholar to search peer-reviewed journals and Google to search "gray" literature for articles on interventions in prepared-food sources. Gray literature included newsletters, published (but not peer-reviewed) articles, policy briefs or reports, published trial materials, and conference presentations. Search terms for each engine included the following: "restaurant intervention," "nutrition AND intervention," "fast-food AND intervention," "prepared food intervention," "point of purchase food," "healthy food choices," and "restaurant health food choices."

\section{Study selection}

We initially identified 35 potential interventions. All identified food-source interventions were reviewed for inclusion according to the following criteria: 1) a focus on prepared-food sources in public community settings such as carryout, fast-food, and sit-down restaurants (although other intervention components could be included as part of the intervention); 2) a completed impact evaluation (eg, pre-post assessment, use of a comparison group, exposure assessment with or without a comparison group); 3) some form of written documentation (eg, peer-reviewed journal article, newsletter article, other published article, policy brief or report, published trial material, a project's own website or conference presentation) that included a description of the implemented intervention and evaluation findings; and 4) an intervention start date after 1990. Of the original 35 interventions, 19 met these inclusion criteria.

For 4 of the 19 interventions, only website information was available, and because we were unable to obtain further information, these 4 were also excluded from our review. Of the 15 remaining, 2 interventions lacked information on study findings and were therefore excluded. These exclusions left 13 interventions for review, data extraction, and analysis.

\section{Data extraction}

The 2 primary reviewers (S.L.K., B.B.) independently extracted and analyzed data by reviewing all documents. The secondary reviewer (J.G.) developed the system for extracting data and coding variables. The secondary reviewer also resolved discrepancies noted by the 2 primary reviewers and identified and adjudicated other discrepancies that might affect reliability and analysis (Appendix).

Primary reviewers were instructed to extract data for each variable and to organize data using the intervention as the unit of analysis. We attempted to contact a representative of each intervention to obtain more information. Seven of 13 intervention managers or lead researchers participated in semistructured telephone interviews or e-mail communications (or both) designed to gather additional information needed to complete the data tables and to resolve any inconsistencies. One intervention (Baltimore Healthy Carryouts) was implemented by our team. After the interventions were reviewed, we summarized data in 3 tables: background and intervention approach, evaluation methods used, and study findings. Within each table, we grouped restaurants into 4 categories according to similar characteristics: specialty restaurants, chain restaurants, small local restaurants, and mixed types of restaurants (both local and chain) that did not share characteristics with other restaurants or whose characteristics were not well defined. The primary reviewers organized the information about each study into these tables. The secondary reviewer confirmed data accuracy by using initial review findings, e-mail correspondence, interview transcripts, and extraction and reporting guidelines.

We implemented previously used techniques (14) for analytic assessment of the selected interventions, such as identifying a standard set of quality criteria (eg, randomization and use of control groups) and reporting on the impact among prepared-food sources and consumers. Because of the heterogeneity of outcome data, which did not permit us to calculate summary estimates of impact, meta-analytic techniques were not used.

\section{Results}

Of the 13 interventions (15-49) that met the inclusion criteria, 12 interventions $(15-18,21,22,24-35,37-41,45-48)$ were described in peer-reviewed publications. Personal communications (e-mail correspondence, telephone interviews) $(\mathrm{n}=$ 


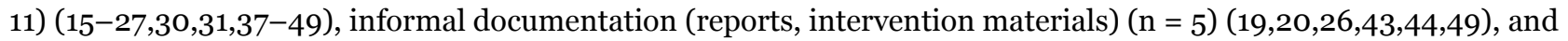
websites $(n=5)(23,36,42,43,49)$ were also sources of information (Table 1a, 1b, 1c, 1d).

\section{Target populations}

Most interventions ( $n=9$ ) took place in urban settings; 3 interventions focused on mixed urban and rural populations, and one focused on rural settings. Interventions were conducted in various regions of the United States: 4 in the Northeast, 4 in the West, 2 in the Midwest, and 1 in the Southeast. Only 2 interventions took place outside the United States (Table 1a, 1b, 1c, 1d). The interventions targeted a range of consumer income levels: 3 interventions (Baltimore Healthy Carryouts [15-23], Steps to a Healthier Salinas [25,26], and Coeur en Santé [28,29] worked in low-income areas, Horgen and Brownell (27) worked in middle- to high-income areas, and the rest did not identify the income level of the targeted population. The race/ethnicity of consumers in the interventions was generally mixed: 5 populations were predominantly white; 1, Hispanic; 1, African American; 1, Korean; and 1, mixed; 4 interventions did not specify the race/ethnicity of the targeted population.

\section{Behavior-change theory}

Ten interventions explicitly stated the theoretical frameworks that guided their design (15-23,25-30,32-49). The theory most commonly identified was social marketing $(n=3)$, used by Winners Circle (47-49), TrEAT Yourself Well (30), and Baltimore Healthy Carryouts (15-23). No other theory was identified by more than 1 trial; however, an emphasis on changing the food environment was mentioned in Baltimore Healthy Carryouts (15-23), Horgen and Brownell (27), and Shape Up Somerville (32-36).

\section{Intervention goals}

Overall, the 13 interventions shared similar goals. All sought to promote more healthful menu items at prepared-food sources with the associated goal of increasing sales of these foods. Some interventions had additional goals. The larger goal of Shape Up Somerville (32-36) was to reduce childhood obesity, and their restaurant intervention (33) was viewed as an environmental component of that work. The additional goal of Baltimore Healthy Carryouts (15-23) was to assess the feasibility of a carryout intervention. Other projects stated that they sought to achieve their overall goals by specific means, such as menu labeling (Tandon et al [31] and Smart Menu program [37,38]) and price changes (Horgen and Brownell [27]).

\section{Formative research}

Three interventions $(30,31,43)$ conducted no formative research before designing and implementing their program. Of the 10 that conducted formative research, 2 reported "informal" research $(27,37,38)$, consisting mainly of literature reviews and discussions with a small number of stakeholders. The remaining 8 interventions did more extensive formative research, including qualitative (eg, focus groups, in-depth interviews) and quantitative (eg, surveys) data collection. Some interventions published separate reports on their formative research $(15,18,21,22,25,28,41,45,46,49)$.

\section{Intervention strategies}

Food promotion

All interventions focused on identifying and promoting existing healthful food options at prepared-food sources as the primary intervention strategy. Five interventions identified specific nutritional criteria for a food to be considered healthful (Coeur en Santé [28,29], TrEAT Yourself Well [30], Tandon et al [31], Healthy Howard [43], and Healthy Restaurant [44]). Only 1 intervention (Baltimore Healthy Carryouts [15-23]) introduced new healthful options: lower-fat side dishes and grilled chicken. All interventions promoted healthful entrées, but 5 interventions also promoted healthful snacks and side dishes: for example, Winners Circle (47-49), Shape Up Somerville (32-36), Baltimore Healthy Carryouts (15-23).

\section{Food preparation or portion size}

Six interventions worked with restaurant owners and staff to develop more healthful recipes, usually by using lower-fat cooking methods (15-23,25,26,28,29,32-38,44-46). Two interventions, Shape Up Somerville (32-36) and the Smart Menu program $(37,38)$, aimed to decrease the portion size of foods served.

Signage and menus

All 13 interventions used some form of signage to promote more healthful options. Most interventions ( $\mathrm{n}=10$ ) used some form of menu labeling, usually a symbol to indicate more healthful choices. Baltimore Healthy Carryouts (15-23) redesigned carryout menus in low-income areas of Baltimore to emphasize more healthful choices. Other forms of signage included posters $(n=4)$ and menu inserts or tablemats $(n=4)$.

Pricing or cost reduction

Four interventions sought to reduce the consumers' cost for the more healthful items. Steps to a Healthier Salinas (25,26) and TrEAT Yourself (30) included coupons or discount cards; Baltimore Healthy Carryouts (15-23) and Horgen and Brownell (27) implemented a price reduction. Baltimore Healthy Carryouts focused on price reductions for combination meals as a strategy $(19,22)$. 


\section{Community promotion}

Four interventions did not promote their programs outside the prepared-food sources or in the general community. Of the 7 interventions that promoted their programs widely, a variety of approaches were used, including newspaper advertisements $(n=5)$, promotion at community events $(n=3)$, and leaflets and newsletters $(n=3)$. These promotions were intended to increase awareness of the program and to direct consumers to prepared-food sources participating in the intervention.

\section{Study design}

Most interventions were nonexperimental interventions in which participation by the prepared-food sources was voluntary $(\mathrm{n}=10)$. Two interventions had a quasi-experimental design: Shape up Somerville (32-36) and TrEAT Yourself Well (30). Baltimore Healthy Carryouts (15-23) used a true experimental design, with random assignment to treatment. Nearly half $(n=6)$ of the interventions $(24,27,37-42,44-46)$ had pre-post assessment at the prepared-food source level with no comparison group (Table 2a, 2b, 2c, 2d).

\section{Evaluation methods used and key findings}

Feasibility and process evaluation of interventions

Most interventions $(n=8)$ collected information on feasibility. In general, this information was in the form of interviews and informal discussions with owners and managers of the prepared-food sources. These same 8 interventions also conducted some form of process evaluation (usually through store visits) to assess, for example, whether signage was displayed and healthful options were available.

Overall, the level of feasibility was moderate to high for intervention implementation (Table 3a, 3b, 3c, 3d). The level of acceptability was generally high among participating food-source owners. Menu labeling was particularly acceptable among multiple interventions. However, no trial assessed program acceptability among consumers.

Findings on process evaluation were more variable. Several interventions were public health interventions with open volunteer enrollment. Many of these interventions had low reach, when assessed by counting customers. We found that interventions had particular difficulty in recruiting restaurants, which was reflected in low reach among restaurants (37,38,47-49). One exception was Healthy Howard, which had moderate reach (43). At least 1 intervention (Shape Up Somerville [32-36]) experienced a decrease in participation over time, whereas others such as Healthy Howard (43) and Healthy Restaurant (44-46) experienced an increase. Only 2 interventions, Baltimore Healthy Carryouts (15-23) and the Healthy Options program (39-42), assessed fidelity; both demonstrated high fidelity. The level of acceptability was high among restaurant owners when the intervention was perceived as less burdensome $\left(15^{-23,28,29,37-42)}\right.$ because of incentives such as free menu analyses, point-of-purchase materials, and media promotions.

\section{Impact of interventions on prepared-food sources}

Seven interventions assessed the impact of the intervention on prepared-food sources. Four of these 7 interventions (Baltimore Healthy Carryouts, Healthy Restaurant, Healthy Howard, and Shape Up Somerville) interviewed food-source owners to assess whether sales of healthful options increased. Four used data from food-source registers; 2 interventions collected sales receipts (Baltimore Healthy Carryouts [15-23] and Horgen and Brownell [27]). Three interventions Healthy Howard (43), Healthy Restaurant (44-46), and Shape Up Somerville (32-36) - collected information other than sales data from the owner or manager of the prepared-food source, including information on nutrition awareness.

When sales were assessed, 5 interventions showed an increase in unit sales of promoted foods. Three interventions Horgen and Brownell (27), Healthy Restaurant (44-46), and Baltimore Healthy Carryouts (15-23) - documented increases in total intervention-associated sales. This finding is best substantiated in Baltimore Healthy Carryouts (1523), which also examined sales in a comparison group of prepared-food sources and demonstrated an increase in total revenue among the intervention group relative to the comparison group $(17,20)$.

Impact of interventions on consumers

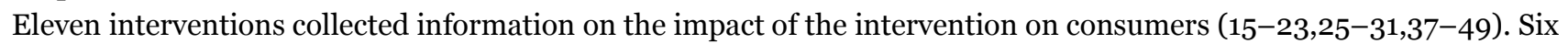
interventions collected data on psychosocial factors such as program awareness and nutrition knowledge (28-31,3742,47-49). Seven interventions collected information on behavior, particularly food choices made at prepared-food sources and frequency of use of prepared-food sources $(15-23,28-31,37-42,47-49)$.

Of the 6 interventions that reported an assessment of psychosocial factors among consumers, most $(n=4)$ found an increased awareness of the intervention and its goals. Of these, Coeur en Santé (29), TrEAT Yourself Well (30), and Healthy Restaurant (44-46) showed improvements in acceptability of healthful food among customers.

Among the 7 interventions that assessed the impact of the intervention on consumer food-related behaviors, only 5 interventions reported results. Four of the 5 interventions (Baltimore Healthy Carryouts [15-23], TrEAT Yourself Well [30], Smart Menu [37,38], and Winners Circle [47-49]) found an increase in the frequency of purchasing the more healthful food options promoted by the intervention. 


\section{Discussion}

This is the first systematic review of interventions in community-based prepared-food sources. Results are promising, showing that cost-effective methods (eg, labeling foods as healthful) may have a significant impact on prepared-food source sales and customer behavior. Most approaches centered on signage to promote existing healthful food choices. Several worked with kitchen staff to improve low-fat food preparation practices, and several conducted formal menu analyses to determine more healthful choices for promotion. These strategies, though resource intensive, show that it is important to engage prepared-food source staff in determining more healthful options.

Although interventions in prepared-food sources are increasingly being considered viable public health interventions, it is clear from this review that the evidence base for these interventions is deficient. Study designs tended to lack comparison groups, treatment conditions were not randomly assigned, and selection criteria were not readily apparent; these inadequacies cast doubt on the generalizability of findings.

Many of the interventions included in this review were not formal studies but rather certification or campaign programs operated by local health departments. These programs were voluntary, which may explain why they varied in levels of reach. Low reach may have been due to the actual burden placed on restaurant owners by the intervention or the lack of potential benefits perceived by them. Partnerships between local public health departments and academic institutions may help overcome some of these limitations through improved social marketing of program strategies and benefits. For example, local public health departments could initiate the intervention and manage recruitment while an academic institution partner conducts a full impact assessment, including psychosocial surveys and sales data collection.

We found no clear preference for a conceptual or behavior-change framework. A few interventions used social marketing approaches, but these interventions generally did not incorporate key social marketing components, such as formative research, audience segmentation, or targeting of messages (50). New frameworks for operationalizing prepared-food source interventions need to be developed; such frameworks should incorporate elements of theories on the food environment $(51,52)$ and behavior change.

Although many interventions showed promising results, most lacked adequate measurement of the impact of the intervention on consumers. Of studies that examined consumer outcomes, most assessed only awareness of the health promotion campaign and food purchasing frequency. More sophisticated assessments - based on behavior-change theories - are needed to evaluate such outcomes as food purchasing patterns and dietary intake.

Almost half of the interventions lacked formal formative research - a major omission, especially considering that food environment research is an emerging area of public health programming. Formative research involves qualitative and quantitative data collection, which aids in program development (53-56); many interventions in our study would have benefited from this kind of preliminary research. In addition, most interventions focused only on promoting existing healthful options at prepared-food sources. Only 1 intervention sought to introduce new, more healthful foods. Interventions need to pay more attention to actively changing the food environment in prepared-food sources by increasing the availability of healthful food options.

Another approach worth exploring is price changes. Two interventions showed positive results by reducing food prices (Baltimore Health Carryouts [15-23] and Horgen and Brownell [27]). Ample evidence supports the use of price reduction as a means of promoting more healthful options among consumers (57-59). Moreover, research on pricing may support the hypothesis that the increased prevalence of obesity may be attributed to greater consumption of soda and chips that have artificially low prices because of government subsidies for corn and soybeans $(4,60,61)$. If nonhealthful and healthful food prices were comparable, consumers might be more likely to purchase healthful foods. Baltimore Healthy Carryouts demonstrated that reducing the price of healthful foods not only increased sales of healthful foods but also increased total carryout revenue $(17,20)$.

Our findings parallel in many ways the findings of recent interventions in small retail food stores (14). Both types of interventions focused on modifying the food environment and promoting healthful choices through point-of-purchase materials. A key difference, however, was that most research on small food stores has focused on food deserts in primarily low-income racial/ethnic minority populations. Only a few of the interventions in our study took place in lowincome settings. More carefully evaluated interventions in food sources in low-income settings are needed. The high rates of obesity and other chronic diseases are related not only to the availability of healthful choices in retail food stores but also to access to healthful foods in prepared-food sources $(15,62-64)$. Although a recent longitudinal study (63) showed mixed results on the relationship between the availability of grocery stores and diet-related outcomes, it demonstrated that the availability of fast food was related to fast food consumption in a low-income population. Low-income populations tend to rely on local prepared-food sources because they often work more than one job and do not have time to cook at home (65). One study found that during the 2007-09 recession, the middle quintile of households (the middle $20 \%$ of the income distribution) cut spending on food away from home by $20 \%$, whereas the lowest quintile of households cut such spending by $12 \%$, suggesting a greater reliance on food away from home among lower quintile households (66). Improving the availability of healthful food in prepared-food sources may be an effective way to promote dietary improvement in low-income settings. 
This systematic review has some limitations. Many of the interventions reviewed were implemented by health departments that lacked the resources to conduct comprehensive evaluations and publish the findings in peer-reviewed publications. Thus, we included findings from the gray literature. Because of the wide variability in measures used and in impact assessments, we were not able to develop summary estimates or compare measures or impacts directly among interventions. These limitations emphasize the need for standardization of measures used by interventions and the need for further reviews that assess different strategies (14).

Our review lays the groundwork for further exploration of strategies to increase more healthful food options in community-based prepared-food sources. Many interventions showed that changing the prepared-food environment may improve sales and awareness of more healthful foods and improve purchasing and consumption behaviors. Interventions can be strengthened through comprehensive formative research and quantitative assessments of process and impacts. With these additions, future studies will be able to assess the relative effectiveness of different strategies and create standards of practice in prepared-food sources.

\section{Acknowledgments}

This review was supported by a Commissioned Analysis grant from the Robert Wood Johnson Foundation's Healthy Eating Research program. Dr Gittelsohn's work in the study was supported in part by a research grant from the Eunice Kennedy Shriver National Institute of Child Health and Human Development (no. U54HD070725), which is cofunded by the National Institute of Child Health and Human Development and the Office of Behavioral and Social Sciences Research at the National Institutes of Health. The content is solely the responsibility of the authors and does not necessarily represent the official views of the funders.

\section{Author Information}

Corresponding Author: Joel Gittelsohn, PhD, Center for Human Nutrition, Johns Hopkins Bloomberg School of Public Health, 615 N Wolfe St, Ste W2041A, Baltimore, MD 21205. Telephone: 410-955-3927. E-mail: jgittels@jhsph.edu.

Author Affiliations: Seung Hee Lee-Kwan, Benjamin Batorsky, Center for Human Nutrition, Johns Hopkins Bloomberg School of Public Health, Baltimore, Maryland.

\section{References}

1. French SA, Story M, Jeffery RW. Environmental influences on eating and physical activity. Annu Rev Public Health 2001;22:309-35. CrossRef 因 PubMed 圈

2. Moore LV, Diez Roux AV, Nettleton JA, Jacobs DR, Franco M. Fast-food consumption, diet quality, and neighborhood exposure to fast food: the Multi-Ethnic Study of Atherosclerosis. Am J Epidemiol 2009;170(1):29-36. CrossRef 圈PubMed 圈

3. Jeffery RW, Baxter J, McGuire M, Linde J. Are fast food restaurants an environmental risk factor for obesity? Int J Behav Nutr Phys Act 2006;3:2. CrossRef 圈 PubMed 圈

4. Story M, Kaphingst KM, Robinson-O'Brien R, Glanz K. Creating healthy food and eating environments: policy and environmental approaches. Annu Rev Public Health 2008;29:253-72. CrossRef 国 PubMed 圈

5. Stewart H, Blisard N, Jolliffe D. Let's eat out: Americans weigh taste, convenience, and nutrition. Economic Information Bulletin. 2006. http://www.ers.usda.gov/media/860870/eib19.pdf. Accessed January 15, 2013.

6. US Department of Agriculture. ERS/USDA Briefing Room - Food CPI and expenditures: Table 10 food away from home as a share of food expenditures. 2011.

http://www.ers.usda.gov/briefing/cpifoodandexpenditures/data/Expenditures_tables/table1o.htm. Accessed March 25, 2013.

7. Riehle H, Grindy B, Altman M. Restaurant industry forecast. National Restaurant Association; 2013. http://www.restaurant.org/News-Research/Research/Forecast-2013. Accessed April 8, 2013.

8. Duffey KJ, Popkin BM. Energy density, portion size, and eating occasions: contributions to increased energy intake in the United States, 1977-2006. PLoS Med 2011;8(6):e1001050. CrossRef 圈 PubMed 圈

9. Kant AK, Graubard BI. Eating out in America, 1987-2000: trends and nutritional correlates. Prev Med 2004;38 (2):243-9. CrossRef 国 PubMed 圈

10. Guthrie JF, Lin BH, Frazao E. Role of food prepared away from home in the American diet, 1977-78 versus 199496: changes and consequences. J Nutr Educ Behav 2002;34(3):140-50. CrossRef 国 PubMed 圈

11. French SA, Harnack L, Jeffery R. Fast food restaurant use among women in the Pound of Prevention study: dietary, behavioral and demographic correlates. Int J Obes Relat Metab Diisord 2000;24(10):1353-9. CrossRef 圈 PubMed 圈 
12. Seymour JD, Yaroch AL, Serdula M, Blanck HM, Khan LK. Impact of nutrition environmental interventions on point-of-purchase behavior in adults: a review. Prev Med 2004;39(Suppl 2):S108-36. CrossRef 橉 PubMed 圈

13. Liberati A, Altman DG, Tetzlaff J, Mulrow C, Gøtzsche PC, Ioannidis JPA, et al. The PRISMA statement for reporting systematic reviews and meta-analyses of studies that evaluate health care interventions: explanation and elaboration. PLoS Med 2009;6(7):e1000100. CrossRef 圈 PubMed 圈

14. Gittelsohn J, Rowan M, Gadhoke P. Interventions in small food stores to change the food environment, improve diet, and reduce risk of chronic disease. Prev Chronic Dis 2012;9:E59. PubMed 0

15. Lee SH, Rowan M, Powell LM, Newman S, Klassen AC, Frick KD, et al. Characteristics of prepared food sources in low-income neighborhoods of Baltimore City. Ecol Food Nutr 2010;49(6):409-30. CrossRef 圈 PubMed 圈

16. Lee SH, Rowan MT, Dennisuk L, Klassen AC, Frick KD, Gittelsohn J. Pilot environmental intervention trial in carryouts in low-income neighborhoods of Baltimore City. FASEB J 2011;25(973):2.

17. Lee SH, Kim H, Yong R, Hamouda M, Shon J, Park JH, et al. Environmental intervention in carryouts increases sales of healthy menu items in low-income urban setting. FASEB J 2012;26(32):7.

18. Lee SH, Hoffman VA, Bleich SN, Gittelsohn J. Frequency of visiting and food dollars spent at carryouts among lowincome, urban African American adults. J Hunger Environ Nutr 2012;7(4):459-67. CrossRef 圈

19. Lee-Kwan SH, Goedkoop S, Yong R, Batorsky B, Hoffman V, Jeffries J, et al. Development and implementation of the Baltimore Healthy Carry-outs feasibility trial: process evaluation results. BMC Public Health 2013;13:638.

20. Lee SH. Changing the food environment in Baltimore City: impact of an intervention to improve carry-outs in lowincome neighborhoods [unpublished doctoral dissertation]. Baltimore (MD): Johns Hopkins University; 2012.

21. Noormohamed A, Lee SH, Batorsky B, Jackson A, Newman S, Gittelsohn J. Factors influencing ordering practices at Baltimore City carryouts: qualitative research to inform an obesity prevention intervention. Ecol Food Nutr 2012;51

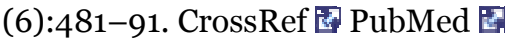

22. Jeffries JK, Lee SH, Frick KD, Gittelsohn J. Preferences for healthy carryout meals in low-income neighborhoods of Baltimore City. Health Promot Pract 2013;14(2):293-300. CrossRef 因 PubMed 圈

23. Baltimore Healthy Carryouts. Johns Hopkins University. http://healthystores.org/projects/baltimore-healthycarryouts/. Accessed January 12, 2013.

24. Eldridge AL, Snyder M, Faus N, Kotz K. Development and evaluation of a labeling program for low-fat foods in a discount department store foodservice area. J Nutr Educ 1997;29(3):159-61. CrossRef 圈

25. Hanni KD, Mendoza E, Snider J, Winkleby MA. A methodology for evaluating organizational change in communitybased chronic disease interventions. Prev Chronic Dis 2007;4(4):A105. PubMed 因

26. Hanni KD, Garcia E, Ellemberg C, Winkleby M. Targeting the taqueria: implementing healthy food options at Mexican American restaurants. Health Promot Pract 2009;10(2 Suppl):91S-9S. CrossRef 娄 PubMed 圈

27. Horgen KB, Brownell KD. Comparison of price change and health message interventions in promoting healthy food choices. Health Psychol 2002;21(5):505-12. CrossRef 国 PubMed 盽

28. Paradis G, O’Loughlin J, Elliott M, Masson P, Renaud L, Sacks-Silver G, et al. Coeur en santé St-Henri - a heart health promotion programme in a low income, low education neighbourhood in Montreal, Canada: theoretical model and early field experience. J Epidemiol Community Health 1995;49(5):503-12. CrossRef 目 PubMed 圈

29. Richard L, O’Loughlin J, Masson P, Devost S. Healthy menu intervention in restaurants in low-income neighbourhoods: a field experience. J Nutr Educ 1999;31(1):54-9. CrossRef 圈

30. Acharya RN, Patterson PM, Hill EP, Schmitz TG, Bohm E. An evaluation of the "TrEAT Yourself Well” restaurant nutrition campaign. Health Educ Behav 2006;33(3):309. CrossRef 因 PubMed 国

31. Tandon PS, Zhou C, Chan NL, Lozano P, Couch SC, Glanz K, et al. The impact of menu labeling on fast-food purchases for children and parents. Am J Prev Med 2011;41(4):434-8. CrossRef 国 PubMed 圈

32. Economos CD, Irish-Hauser S. Community interventions: a brief overview and their application to the obesity epidemic. J Law Med Ethics 2007;35(1):131-7. CrossRef 圈 PubMed 国

33. Economos CD, Folta SC, Goldberg J, Hudson D, Collins J, Baker Z, et al. A community-based restaurant initiative to increase availability of healthy menu options in Somerville, Massachusetts: Shape Up Somerville. Prev Chronic Dis 2009;6(3):A102. PubMed 웅

34. Economos CD, Curtatone JA. Shaping up Somerville: a community initiative in Massachusetts. Prev Med 2010;50 (Suppl 1):S97-8. CrossRef 圈 PubMed 圈

35. Sliwa S, Goldberg JP, Clark V, Junot B, Nahar E, Nelson ME, et al. Using the community readiness model to select communities for a community-wide obesity prevention intervention. Prev Chronic Dis 2011;8(6):A150. PubMed ⿷匚

36. Shape Up Somerville. Tufts University. http://www.nutrition.tufts.edu/index.php?q=research/shapeup-somerville. Accessed January 122013. 
37. Pulos E, Leng K. Evaluation of a voluntary menu-labeling program in full-service restaurants. Am J Public Health 2010;100(6):1035-9. CrossRef 圈 PubMed 圈

38. Britt JW, Frandsen K, Leng K, Evans D, Pulos E. Feasibility of voluntary menu labeling among locally owned restaurants. Health Promot Pract 2011;12(1):18-24. CrossRef : PubMed 圈

39. Nothwehr FK, Snetselaar L, Dawson J, Schultz U. Promoting healthy choices in non-chain restaurants: effects of a simple cue to customers. Health Promot Pract 2013;14(1):132-8. CrossRef 国 PubMed 国

40. Nothwehr F, Andsager J, Haines H. The Rural Restaurant Healthy Options Program: response of rural, local newspapers to a program press release. Health Promot Pract 2012.

41. Nothwehr F, Snetselaar L, Dawson JD, Hradek C, Sepulveda M. Healthy option preferences of rural restaurant customers. Health Promot Pract 2010;11(6):828-36. CrossRef 圈 PubMed 圈

42. Toolkit materials for the Healthy Options Program. Prevention Research Center for Rural Health. Iowa City (IA): University of Iowa. http://cph.uiowa.edu/prc/IDPHtoolkit.html. Accessed January 14, 2013.

43. Healthy Howard. Look for certified healthy restaurants. 2012. http://www.healthyhowardmd.org/healthyhoward/healthy-restaurants. Accessed April 18, 2012.

44. Joung H. Effectiveness evaluation of Healthy Restaurant Program. Seoul National University School of Public Health and Management Center for Health Promotion; 2008. Report No: 07-26.

http://research.hp.go.kr/hpResearch/rsrptTma.dia?

method=detailView\&RSR_IDX $=575 \&$ mnid $=021202000000 \&$ searchCount $=0 \&$ searchLine $=\&$ page $=13 \&$ outLine $=10$. Accessed October 10, 2012.

45. Hong K, Joung H. Restaurateur's willingness to participate in the Healthy Restaurant Program in Seoul. Korean J Nutr 2009;42(3):268-277. CrossRef 圈

46. Hong K, Gittelsohn J, Joung H. Determinants of customers' intention to participate in a Korean restaurant health promotion program: an application of the theory of planned behavior. Health Promot Int 2010;25(2):174-82. CrossRef 国 PubMed 圈

47. Molloy M. Practice notes: strategies in health education. Winner's Circle Healthy Dining Program. Health Educ Behav 2002;29:406-8.

48. Shovelin K, Molloy M, Yum D, Shirah K, Andersen K, Ezzell J, et al. Changing the environment in which consumers dine: the Winner's Circle Healthy Dining Program. Preventing overweight and obesity: policy and environmental approaches. Conference proceedings from the 131st annual meeting of American Public Health Association. 2003 Nov 15-19; San Francisco, California. https://apha.confex.com/apha/131am/techprogram/paper_62943.htm. Accessed January 12, 2013.

49. Winner's circle FAQs. NC Prevention Partners. http://www.ncpreventionpartners.org/dnn/WhatWeDo/Programs/WinnersCircle/tabid/159/Default.aspx. Accessed January 12, 2013.

50. Storey J, Saffitz G, Rimon J. Social marketing. In: Glanz K, Rimer BK, Viswanath K, editors. Health behavior and health education: theory, research and practice. 4th edition. San Fransisco (CA): Jossey-Bass; 2008 . p. 435-61.

51. Glanz K. Measuring food environments: a historical perspective. Am J Prev Med 2009;36(4, Suppl):S93-8. CrossRef 国 PubMed 圈

52. Glanz K, Sallis JF, Saelens BE, Frank LD. Healthy nutrition environments: concepts and measures. Am J Health Promot 2005;19(5):330-3, ii. CrossRef 橉 PubMed 圈

53. Gittelsohn J, Steckler A, Johnson CC, Pratt C, Grieser M, Pickrel J, et al. Formative research in school and community-based health programs and studies: "state of the art" and the TAAG approach. Health Educ Behav 2006;33(1):25. CrossRef 国 PubMed 国

54. Gittelsohn J, Dyckman W, Tan ML, Boggs MK, Frick KD, Alfred J, et al. Development and implementation of a food store-based intervention to improve diet in the Republic of the Marshall Islands. Health Promot Pract 2006;7

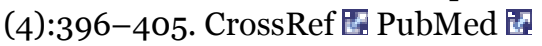

55. Gittelsohn J, Harris SB, Whitehead S, Wolever TMS, Hanley J, Barnie A, et al. Developing diabetes interventions in an Ojibwa-Cree community in northern Ontario: linking qualitative and quantitative data. Chronic Dis Can 1995;16 (4):157-64.

56. Strolla LO, Gans KM, Risica PM. Using qualitative and quantitative formative research to develop tailored nutrition intervention materials for a diverse low-income audience. Health Educ Res 2006;21(4):465. CrossRef 国 PubMed 圈

57. Cummins S, Petticrew M, Higgins C, Findlay A, Sparks L. Large scale food retailing as an intervention for diet and health: quasi-experimental evaluation of a natural experiment. J Epidemiol Community Health 2005;59(12):103540. CrossRef 国 PubMed 因 
58. Reger B, Wootan MG, Booth-Butterfield S. Using mass media to promote healthy eating: a community-based demonstration project. Prev Med 1999;29(5):414-21. CrossRef 圈 PubMed 圈

59. Gittelsohn J, Sharma S. Physical, consumer, and social aspects of measuring the food environment among diverse low-income populations. Am J Prev Med 2009;36(4, Suppl):S161-5. CrossRef : PubMed 圈

60. Andreyeva T, Long MW, Brownell KD. The impact of food prices on consumption: a systematic review of research on the price elasticity of demand for food. Am J Public Health 2010;100(2):216-22. CrossRef 国 PubMed $\mathrm{E}$

61. Alston JM, Sumner DA, Vosti SA. Farm subsidies and obesity in the United States: national evidence and international comparisons. Food Policy 2008;33(6):470-9. CrossRef 圈

62. Neff RA, Palmer AM, McKenzie SE, Lawrence RS. Food systems and public health disparities. J Hunger Environ Nutr 2009;4(3-4):282-314. CrossRef 圈 PubMed 圈

63. Boone-Heinonen J, Gordon-Larsen P, Kiefe CI, Shikany JM, Lewis CE, Popkin BM. Fast food restaurants and food stores: longitudinal associations with diet in young to middle-aged adults: the CARDIA study. Arch Intern Med 2011;171(13):1162-70. CrossRef 圈 PubMed 圈

64. Richardson AS, Boone-Heinonen J, Popkin BM, Gordon-Larsen P. Neighborhood fast food restaurants and fast food consumption: a national study. BMC Public Health 2011;11(1):543. CrossRef 圈 PubMed 国

65. Devine CM, Connors MM, Sobal J, Bisogni CA. Sandwiching it in: spillover of work onto food choices and family roles in low- and moderate-income urban households. Soc Sci Med 2003;56(3):617-30. CrossRef 国 PubMed 国

66. Kumcu A, Kaufman P. Food spending adjustments during recessionary times. US Department of Agriculture Economic Research Service. 2011. http://www.ers.usda.gov/amber-waves/2011-september/foodspending.aspx\#.UVCJileNDKU. Accessed March 25, 2013.

\section{Tables}

Table 1a. Key Components of Interventions on Community-based PreparedFood Sources: Interventions Conducted in Specialty Restaurantsa

\begin{tabular}{|c|c|c|c|c|}
\hline Characteristic & $\begin{array}{l}\text { Baltimore Healthy } \\
\text { Carryouts (15-23) }\end{array}$ & Good for You (24) & $\begin{array}{l}\text { Steps to a Healthier } \\
\text { Salinas }(25,26)\end{array}$ & $\begin{array}{c}\text { Horgen and } \\
\text { Brownell } 2002 \\
(27)\end{array}$ \\
\hline Data sources & $\begin{array}{l}\text { Peer-reviewed articles; } \\
\text { conference } \\
\text { presentation; website }\end{array}$ & $\begin{array}{l}\text { Peer-reviewed article; e-mail } \\
\text { correspondence }\end{array}$ & $\begin{array}{l}\text { Peer-reviewed articles; } \\
\text { interview; e-mail } \\
\text { correspondence; } \\
\text { intervention materials }\end{array}$ & $\begin{array}{l}\text { Peer-reviewed } \\
\text { article; interview }\end{array}$ \\
\hline $\begin{array}{l}\text { Target } \\
\text { population }\end{array}$ & $\begin{array}{l}\text { Baltimore; African } \\
\text { American; low- } \\
\text { income; urban }\end{array}$ & $\begin{array}{l}\text { Minnesota; Target store } \\
\text { customers }\end{array}$ & $\begin{array}{l}\text { Salinas, California; low } \\
\text {-income; mostly } \\
\text { Mexican American }\end{array}$ & $\begin{array}{l}\text { New Haven, } \\
\text { Connecticut; } \\
\text { delicatessen } \\
\text { customers; mostly } \\
\text { white, upper-middle } \\
\text { class }\end{array}$ \\
\hline Model/theory & $\begin{array}{l}\text { Social cognitive } \\
\text { theory; Social } \\
\text { marketing }\end{array}$ & Not specified & $\begin{array}{l}\text { Socioecological model; } \\
\text { asset-based } \\
\text { community } \\
\text { development }\end{array}$ & $\begin{array}{l}\text { Matching model; } \\
\text { health belief model }\end{array}$ \\
\hline Goals & $\begin{array}{l}\text { Awareness; } \\
\text { availability; } \\
\text { affordability; } \\
\text { consumption }\end{array}$ & Awareness; consumption & $\begin{array}{l}\text { Awareness; } \\
\text { consumption; } \\
\text { availability }\end{array}$ & $\begin{array}{l}\text { Awareness; } \\
\text { consumption; } \\
\text { affordability }\end{array}$ \\
\hline $\begin{array}{l}\text { Types of } \\
\text { prepared-food } \\
\text { sources }\end{array}$ & $\begin{array}{l}\text { Carryout restaurants } \\
\text { serving mainly deep- } \\
\text { fried foods }\end{array}$ & $\begin{array}{l}\text { Cafeteria in large general } \\
\text { merchandise/department } \\
\text { store }\end{array}$ & $\begin{array}{l}\text { Mexican-style } \\
\text { restaurants }\end{array}$ & Delicatessen \\
\hline $\begin{array}{l}\text { Food targeted } \\
\text { in intervention }\end{array}$ & $\begin{array}{l}\text { Low-fat, low- } \\
\text { cholesterol entrées, } \\
\text { sides, and beverages }\end{array}$ & 15 Low-fat items on menu & $\begin{array}{l}\text { Healthier preparations } \\
\text { for dishes; } \\
\text { replacement of lard } \\
\text { with vegetable oil for } \\
\text { cooking }\end{array}$ & $\begin{array}{l}\text { Low-fat meals and } \\
\text { sides }\end{array}$ \\
\hline \multicolumn{5}{|c|}{ Intervention strategies } \\
\hline
\end{tabular}




\begin{tabular}{|c|c|c|c|c|}
\hline Characteristic & $\begin{array}{l}\text { Baltimore Healthy } \\
\text { Carryouts (15-23) }\end{array}$ & Good for You (24) & $\begin{array}{c}\text { Steps to a Healthier } \\
\text { Salinas }(25,26)\end{array}$ & $\begin{array}{c}\text { Horgen and } \\
\text { Brownell } 2002 \\
(27)\end{array}$ \\
\hline Signage & $\begin{array}{l}\text { Menu board; menu } \\
\text { labeling; point-of- } \\
\text { purchase posters }\end{array}$ & $\begin{array}{l}\text { Menu labeling; point-of- } \\
\text { purchase materials (table } \\
\text { tents, tray liners) }\end{array}$ & $\begin{array}{l}\text { Point-of-purchase } \\
\text { materials (logo on } \\
\text { menu and signage) }\end{array}$ & $\begin{array}{l}\text { Price reduction } \\
\text { messages; point-of } \\
\text { purchase materials } \\
\text { (signs, posters) }\end{array}$ \\
\hline $\begin{array}{l}\text { Increased } \\
\text { availability of } \\
\text { healthful foods }\end{array}$ & $\begin{array}{l}\text { Fresh fruits, yogurts, } \\
\text { healthful sides, and } \\
\text { grilled chicken } \\
\text { sandwich }\end{array}$ & None & $\begin{array}{l}\text { Healthful preparation } \\
\text { strategies; fresh fruit } \\
\text { juices }\end{array}$ & None \\
\hline Pricing & $\begin{array}{l}\text { Reduced-price } \\
\text { combination meals }\end{array}$ & None & $\begin{array}{l}\text { Coupons ( } 10 \% \\
\text { discount) }\end{array}$ & $\begin{array}{l}20 \%-30 \% \text { price } \\
\text { reduction of low-fat } \\
\text { items }\end{array}$ \\
\hline $\begin{array}{l}\text { Community } \\
\text { components }\end{array}$ & None & None & None & None \\
\hline Other & None & None & $\begin{array}{l}\text { Healthy Nutrition Tool } \\
\text { kit; give-aways }\end{array}$ & None \\
\hline $\begin{array}{l}\text { Formative } \\
\text { research }\end{array}$ & $\begin{array}{l}\text { Semi-structured } \\
\text { interview with } \\
\text { customers }(N=50) \\
\text { and owners }(N=12) ; \\
\text { focus groups, conjoint } \\
\text { analysis }(N=50)\end{array}$ & $\begin{array}{l}\text { Customer survey of interest } \\
\text { in buying lower-fat foods at } \\
\text { Target Food Avenue }\end{array}$ & $\begin{array}{l}\text { Surveys of local } \\
\text { taquerias; work with } \\
\text { owners to identify } \\
\text { intervention strategies }\end{array}$ & $\begin{array}{l}\text { Informal discussions } \\
\text { with restaurant } \\
\text { managers and staff }\end{array}$ \\
\hline
\end{tabular}

a Includes restaurants, such as carryouts, taquerias, and delicatessen cafés, that focused on specialty foods; it excludes chain fast-food restaurants.

Table 1b. Key Components of Interventions on Community-based PreparedFood Sources: Interventions Conducted in Chain Restaurants

\begin{tabular}{|c|c|c|c|}
\hline Characteristic & Coeur en Santé St-Henri $(28,29)$ & TrEAT Yourself Well (30) & $\begin{array}{c}\text { Tandon et al } 2011 \\
\text { (31) }\end{array}$ \\
\hline Data sources & Peer-reviewed article & $\begin{array}{l}\text { Peer-reviewed article; e-mail } \\
\text { correspondence }\end{array}$ & $\begin{array}{l}\text { Peer-reviewed article; e- } \\
\text { mail correspondence }\end{array}$ \\
\hline Target population & $\begin{array}{l}\text { Montreal; restaurant customers; low- } \\
\text { income }\end{array}$ & $\begin{array}{l}\text { San Diego area; restaurant } \\
\text { customers; mostly white }\end{array}$ & $\begin{array}{l}\text { Seattle and San Diego; } \\
\text { children aged 6-11 years } \\
\text { and parents }\end{array}$ \\
\hline Model/Theory & Social learning theory & $\begin{array}{l}\text { Theory of reasoned action; } \\
\text { social marketing }\end{array}$ & None specified \\
\hline Goal & Awareness; consumption & Awareness; consumption & Awareness; consumption \\
\hline $\begin{array}{l}\text { Types of prepared- } \\
\text { food sources }\end{array}$ & $\begin{array}{l}\text { Fast-food restaurant and family-style } \\
\text { restaurant }\end{array}$ & 4 chain restaurants & Chain restaurants \\
\hline $\begin{array}{l}\text { Food targeted in } \\
\text { intervention }\end{array}$ & Low-fat, high-fiber items on menus & $\begin{array}{l}\text { Low-fat menu items } \\
\text { containing fruits and } \\
\text { vegetables }\end{array}$ & Chain restaurant foods \\
\hline \multicolumn{4}{|c|}{ Intervention strategies } \\
\hline Signage & Menu labeling & $\begin{array}{l}\text { Point-of-purchase materials } \\
\text { (table tents, posters) }\end{array}$ & Menu labeling \\
\hline $\begin{array}{l}\text { Increased } \\
\text { availability of } \\
\text { healthful foods }\end{array}$ & $\begin{array}{l}\text { Recipe modification to increase fiber or } \\
\text { decrease fat }\end{array}$ & None & None \\
\hline Pricing & None & Discount cards & None \\
\hline $\begin{array}{l}\text { Community } \\
\text { components }\end{array}$ & Media (newspaper, telephone, leaflets) & & None \\
\hline
\end{tabular}




\begin{tabular}{|l|l|l|l|}
\hline Characteristic & \multicolumn{1}{|c|}{ Coeur en Santé St-Henri (28,29) } & TrEAT Yourself Well (30) & $\begin{array}{c}\text { Tandon et al 2011 } \\
\text { (31) }\end{array}$ \\
\hline & & $\begin{array}{l}\text { Community events and food } \\
\text { tasting; media (television, } \\
\text { magazines, newspaper) }\end{array}$ & None \\
\hline Other & None & Wait-staff incentives & None \\
\hline Formative research & $\begin{array}{l}\text { Community informants identify popular } \\
\text { restaurants; dietitian review of menu } \\
\text { options via interviews with kitchen staff } \\
\text { supervisor and suppliers }\end{array}$ & None & \\
\hline
\end{tabular}

Table 1c. Key Components of Interventions on Community-based PreparedFood Sources: Interventions Conducted in Small Local Restaurantsa

\begin{tabular}{|c|c|c|c|}
\hline Characteristic & Shape Up Somerville (32-36) & $\begin{array}{c}\text { Smart Menu Program } \\
(37,38)\end{array}$ & $\begin{array}{l}\text { The Healthy Options } \\
\text { Program (39-42) }\end{array}$ \\
\hline Data sources & Peer-reviewed articles; website & $\begin{array}{l}\text { Peer-reviewed articles; e-mail } \\
\text { correspondence }\end{array}$ & $\begin{array}{l}\text { Peer-reviewed article; } \\
\text { website; e-mail } \\
\text { correspondence }\end{array}$ \\
\hline $\begin{array}{l}\text { Target } \\
\text { population }\end{array}$ & $\begin{array}{l}\text { Somerville, Massachusetts; restaurant } \\
\text { customers; students in 1st-3rd grade }\end{array}$ & $\begin{array}{l}\text { Tacoma-Pierce County, } \\
\text { Washington; restaurant } \\
\text { customers; mostly white }\end{array}$ & $\begin{array}{l}\text { Rural Iowa; mostly } \\
\text { white }\end{array}$ \\
\hline Model/Theory & Community-based participatory research & Diffusion of innovations & Social cognitive theory \\
\hline Goal & Awareness; availability & Awareness; consumption & $\begin{array}{l}\text { Awareness; } \\
\text { consumption }\end{array}$ \\
\hline $\begin{array}{l}\text { Types of } \\
\text { prepared-food } \\
\text { sources }\end{array}$ & Various participating restaurants & $\begin{array}{l}\text { Various participating locally } \\
\text { owned restaurants }\end{array}$ & $\begin{array}{l}\text { Various locally owned } \\
\text { restaurants }\end{array}$ \\
\hline $\begin{array}{l}\text { Food targeted in } \\
\text { interventions }\end{array}$ & Half-size portions; low-fat milk or water & Meal and dessert items & $\begin{array}{l}\text { Low-fat dressings, milk, } \\
\text { meat, sides, breakfast } \\
\text { items, desserts, whole- } \\
\text { wheat bread }\end{array}$ \\
\hline \multicolumn{4}{|c|}{ Intervention strategies } \\
\hline Signage & $\begin{array}{l}\text { Menu labeling; point-of-purchase materials } \\
\text { (logo and signs, menu inserts) }\end{array}$ & Menu labeling & $\begin{array}{l}\text { Point-of-purchase } \\
\text { materials (table } \\
\text { placard, poster) }\end{array}$ \\
\hline $\begin{array}{l}\text { Increased } \\
\text { availability of } \\
\text { healthful foods }\end{array}$ & $\begin{array}{l}\text { Half-sized portions of entrées; fruit and } \\
\text { vegetable side dishes; low-fat milk or } \\
\text { water }\end{array}$ & $\begin{array}{l}\text { Encouragement of addition of } \\
\text { healthful items, preparations, } \\
\text { smaller portion sizes }\end{array}$ & None \\
\hline Pricing & None & None & None \\
\hline $\begin{array}{l}\text { Community } \\
\text { components }\end{array}$ & $\begin{array}{l}\text { Improved walkability and environmental } \\
\text { policies; community advocates } \\
\text { established; farmers market program; } \\
\text { newspaper ads }\end{array}$ & $\begin{array}{l}\text { Media (newsletters, } \\
\text { newspapers, websites) }\end{array}$ & Media (newspaper) \\
\hline Other & None & Free menu analysis & None \\
\hline $\begin{array}{l}\text { Formative } \\
\text { research }\end{array}$ & $\begin{array}{l}\text { Meetings, focus groups, and interviews } \\
\text { with owners/managers; advisory council; } \\
\text { approval criteria were refined with } \\
\text { feedbacks from restaurant owners and } \\
\text { managers; unable to complete } 3 \text { focus } \\
\text { groups with restaurants }\end{array}$ & $\begin{array}{l}\text { Menu labeling literature } \\
\text { review; consulted food } \\
\text { industry representative and } \\
\text { health advisory group; no } \\
\text { formal formative research } \\
\text { phase. }\end{array}$ & $\begin{array}{l}\text { Pilot survey to indicate } \\
\text { customer preferences; } \\
\text { presented to owners }\end{array}$ \\
\hline
\end{tabular}

a Includes small, locally owned "mom-and-pop" establishments that include but are not limited to take-out and sit-down restaurants and restaurants that focused on specialty foods; it excludes chain restaurants. 
Table 1d. Key Components of Interventions on Community-based PreparedFood Sources: Interventions Conducted in Mixed Types of Restaurantsa

\begin{tabular}{|c|c|c|c|}
\hline Characteristic & $\begin{array}{l}\text { Healthy Howard Initiative } \\
\text { (43) }\end{array}$ & $\begin{array}{c}\text { Healthy Restaurant Program (44- } \\
46)\end{array}$ & $\begin{array}{c}\text { Winners Circle Healthy } \\
\text { Dining Program (47- } \\
\text { 49) }\end{array}$ \\
\hline Data sources & $\begin{array}{l}\text { Interview; website; printed } \\
\text { materials; e-mail } \\
\text { correspondence }\end{array}$ & $\begin{array}{l}\text { Peer-reviewed article; research report; } \\
\text { interview }\end{array}$ & $\begin{array}{l}\text { Peer-reviewed article; } \\
\text { conference presentation; } \\
\text { website; e-mail } \\
\text { correspondence }\end{array}$ \\
\hline Target population & $\begin{array}{l}\text { Howard County, Maryland; } \\
\text { restaurant customers }\end{array}$ & $\begin{array}{l}\text { Seoul, South Korea; restaurant } \\
\text { customers }\end{array}$ & $\begin{array}{l}65 \text { North Carolina } \\
\text { counties; mixed } \\
\text { race/ethnicity }\end{array}$ \\
\hline Model/theory & $\begin{array}{l}\text { Community-based } \\
\text { environmental change } \\
\text { initiative }\end{array}$ & Community capacity analysis & $\begin{array}{l}\text { Social marketing; } \\
\text { community-based } \\
\text { environmental-change } \\
\text { initiative }\end{array}$ \\
\hline Goal & Awareness; consumption & Awareness; consumption & Awareness; consumption \\
\hline $\begin{array}{l}\text { Types of prepared } \\
\text {-food sources }\end{array}$ & $\begin{array}{l}\text { Various participating } \\
\text { restaurants }\end{array}$ & Various participating restaurants & $\begin{array}{l}\text { Various participating } \\
\text { restaurants }\end{array}$ \\
\hline $\begin{array}{l}\text { Food targeted in } \\
\text { interventions }\end{array}$ & $\begin{array}{l}\text { Healthful entrées that meet } \\
\text { nutritional criteria }\end{array}$ & $\begin{array}{l}\text { Healthful menu items that meet } \\
\text { nutritional criteria }\end{array}$ & $\begin{array}{l}\text { Meals, side items, snacks } \\
\text { and beverages good for } \\
\text { "heart health" }\end{array}$ \\
\hline \multicolumn{4}{|c|}{ Intervention strategies } \\
\hline Signage & $\begin{array}{l}\text { Menu labeling; point-of- } \\
\text { purchase materials (window } \\
\text { decal and certificate, } \\
\text { nutrition sheets) }\end{array}$ & $\begin{array}{l}\text { Menu labeling; point-of-purchase } \\
\text { materials (photos, menu boards, } \\
\text { posters, logo on restaurant) }\end{array}$ & $\begin{array}{l}\text { Point-of-purchase } \\
\text { materials (logo on menu, } \\
\text { promoted items) }\end{array}$ \\
\hline $\begin{array}{l}\text { Increased } \\
\text { availability of } \\
\text { healthful foods }\end{array}$ & $\begin{array}{l}\text { Trans fat-free; healthful } \\
\text { menu options }\end{array}$ & Foods that meet nutritional standards & None \\
\hline Pricing & $\begin{array}{l}\text { Discounts (planned, not yet } \\
\text { implemented) }\end{array}$ & None & None \\
\hline $\begin{array}{l}\text { Community } \\
\text { components }\end{array}$ & $\begin{array}{l}\text { Media (newspaper, } \\
\text { magazine, websites); } \\
\text { community events }\end{array}$ & $\begin{array}{l}\text { Media (newspaper, website); } \\
\text { community events }\end{array}$ & $\begin{array}{l}\text { Media (billboards, } \\
\text { television) }\end{array}$ \\
\hline Other & $\begin{array}{l}\text { Comply with the "Clean } \\
\text { Indoor Air Act"; pass food } \\
\text { inspections; allergen } \\
\text { labeling on menu }\end{array}$ & None & $\begin{array}{l}\text { Nutritional information in } \\
\text { booklets or brochures in } \\
\text { some locations }\end{array}$ \\
\hline $\begin{array}{l}\text { Formative } \\
\text { research }\end{array}$ & None & $\begin{array}{l}\text { Survey of customers and restaurant } \\
\text { workers for information on how to } \\
\text { design intervention; focus groups with } \\
\text { restaurant workers; in-depth interviews } \\
\text { with consumers }\end{array}$ & $\begin{array}{l}\text { Pilot in } 2 \text { North Carolina } \\
\text { counties; intercept } \\
\text { interviews }\end{array}$ \\
\hline
\end{tabular}

a Includes restaurants (both local and chain) that did not share characteristics with other intervention restaurants or whose characteristics were not well defined.

Table 2a. Evaluation Methods Used by Interventions on Prepared-Food Sources, by Type of Intervention: Interventions Conducted in Specialty Restaurantsa 


\begin{tabular}{|c|c|c|c|c|}
\hline Characteristic & $\begin{array}{c}\text { Baltimore } \\
\text { Healthy } \\
\text { Carryouts (15- } \\
\text { 23) }\end{array}$ & Good for You (24) & $\begin{array}{l}\text { Steps to a Healthier } \\
\text { Salinas }(25,26)\end{array}$ & $\begin{array}{c}\text { Horgen and } \\
\text { Brownell } 2002 \\
(27)\end{array}$ \\
\hline Study design & $\begin{array}{l}\text { Experimental } \\
\text { design; pre-post } \\
\text { assessment }(n=8)\end{array}$ & $\begin{array}{l}\text { Nonexperimental; pre- } \\
\text { post sales analysis, broken } \\
\text { down by quarter }(n=7)\end{array}$ & $\begin{array}{l}\text { Nonexperimental; no pre- } \\
\text { post assessment; } \\
\text { intervention trial, voluntary } \\
\text { participation; no comparison } \\
\text { group }(\mathrm{n}=16)\end{array}$ & $\begin{array}{l}\text { Nonexperimental; } \\
\text { pre-post assessment } \\
(\mathrm{n}=1)\end{array}$ \\
\hline $\begin{array}{l}\text { Feasibility } \\
\text { assessment } \\
\text { measuresb }\end{array}$ & $\begin{array}{l}\text { Informal } \\
\text { observation; staff } \\
\text { reports; interviews } \\
\text { with carryout } \\
\text { owners or staff }\end{array}$ & $\begin{array}{l}\text { Launched simultaneously } \\
\text { in all Target Food Avenue } \\
\text { restaurants; not assessed } \\
\text { at individual store level }\end{array}$ & $\begin{array}{l}\text { Assessments, discussion } \\
\text { with health educators }\end{array}$ & $\begin{array}{l}\text { Informal visits, daily } \\
\text { check-in }\end{array}$ \\
\hline $\begin{array}{l}\text { Process } \\
\text { evaluation } \\
\text { measuresc }\end{array}$ & Direct observation & None & $\begin{array}{l}\text { Surveys with store owners; } \\
\text { informal observation }\end{array}$ & $\begin{array}{l}\text { Informal visits, daily } \\
\text { check-in }\end{array}$ \\
\hline $\begin{array}{l}\text { Prepared-food } \\
\text { source impact } \\
\text { measures }\end{array}$ & Sales & Sales & None & Sales \\
\hline $\begin{array}{l}\text { Consumer } \\
\text { impact } \\
\text { measuresd }\end{array}$ & $\begin{array}{l}\text { Purchasing; } \\
\text { awareness; self- } \\
\text { reported body mass } \\
\text { index }\end{array}$ & None & $\begin{array}{l}\text { Modified Behavioral Risk } \\
\text { Factor Surveillance System }\end{array}$ & Behavior \\
\hline
\end{tabular}

a Includes restaurants, such as carryouts, taquerias, and delicatessen cafés, that focused on specialty foods; it excludes chain fast-food restaurants.

b Feasibility assessment measures include acceptability, operability, and perceived sustainability.

c Process evaluation measures include dose, reach, and fidelity, which indicate how well the program was implemented according to plan.

d Consumer impact measures included psychosocial, behavioral, and health outcomes.

Table 2b. Evaluation Methods Used by Interventions on Prepared-Food Sources, by Type of Intervention: Interventions Conducted in Chain Restaurants

\begin{tabular}{|l|l|l|l|}
\hline Characteristic & \multicolumn{1}{|c|}{$\begin{array}{c}\text { Coeur en Santé St-Henri } \\
(\mathbf{2 8 , 2 9 )}\end{array}$} & \multicolumn{1}{|c|}{ TrEAT Yourself Well (30) } & $\begin{array}{c}\text { Tandon et al 2011 } \\
\mathbf{( 3 1 )}\end{array}$ \\
\hline Study design & $\begin{array}{l}\text { Nonexperimental; no pre- } \\
\text { post assessment }(\mathrm{n}=2)\end{array}$ & $\begin{array}{l}\text { Quasi-experimental; no pre-post } \\
\text { assessment; comparison regions ( } \\
=4)\end{array}$ & $\begin{array}{l}\text { Pre-post assessment; } \\
\text { comparison counties }\end{array}$ \\
\hline $\begin{array}{l}\text { Feasibility assessment } \\
\text { measuresa }\end{array}$ & None & None & None specified \\
\hline $\begin{array}{l}\text { Process evaluation } \\
\text { measuresb }\end{array}$ & None & None & None specified \\
\hline $\begin{array}{l}\text { Prepared-food source } \\
\text { impact measures }\end{array}$ & None & None & None \\
\hline $\begin{array}{l}\text { Consumer impact } \\
\text { measuresc }\end{array}$ & Purchasing; attitudes & Awareness; attitudes & $\begin{array}{l}\text { Awareness; behavior } \\
\text { (calories consumed) }\end{array}$ \\
\hline
\end{tabular}

a Feasibility assessment measures include acceptability, operability, and perceived sustainability.

b Process evaluation measures include dose, reach, and fidelity, which indicate how well the program was implemented according to plan.

c Consumer impact measures included psychosocial, behavioral, and health outcomes. 
Table 2c. Evaluation Methods Used by Interventions on PreparedFood Sources, by Type of Intervention: Interventions Conducted in Small Local Restaurantsa

\begin{tabular}{|l|l|l|l|}
\hline Characteristic & \multicolumn{1}{|c|}{ Shape Up Somerville (32-36) } & Smart Menu Program (37,38) & $\begin{array}{l}\text { The Healthy Options } \\
\text { Program (39-42) }\end{array}$ \\
\hline Study design & $\begin{array}{l}\text { Quasi-experimental; } \\
\text { nonexperimental for restaurant } \\
\text { portion of intervention; intervention } \\
\text { trial, voluntary participation }(\mathrm{n}=21)\end{array}$ & $\begin{array}{l}\text { Nonexperimental; pre-post } \\
\text { assessment; intervention trial, } \\
\text { voluntary participation; no } \\
\text { comparison group (n = 6) }\end{array}$ & $\begin{array}{l}\text { Nonexperimental; pre- } \\
\text { post assessment (n = } \\
\text { 4) }\end{array}$ \\
\hline $\begin{array}{l}\text { Feasibility } \\
\text { assessment } \\
\text { measuresb }\end{array}$ & $\begin{array}{l}\text { Environmental change assessment; } \\
\text { owners' compliance and perceived } \\
\text { impact }\end{array}$ & $\begin{array}{l}\text { Interviews with restaurant owners } \\
\text { or managers }\end{array}$ & $\begin{array}{l}\text { Interviews with owner } \\
\text { and staff }\end{array}$ \\
\hline $\begin{array}{l}\text { Process } \\
\text { evaluation } \\
\text { measuresc }\end{array}$ & $\begin{array}{l}\text { Extensive process evaluation; } \\
\text { participation and adherence to } \\
\text { intervention elements }\end{array}$ & $\begin{array}{l}\text { Observation of nutrition } \\
\text { information being posted }\end{array}$ & None \\
\hline $\begin{array}{l}\text { Prepared-food } \\
\text { source impact } \\
\text { measures }\end{array}$ & $\begin{array}{l}\text { Owner survey (menu changes, sales, } \\
\text { nutrition awareness) }\end{array}$ & Sales & Sales \\
\hline $\begin{array}{l}\text { Consumer impact } \\
\text { measuresd }\end{array}$ & $\begin{array}{l}\text { None for restaurant intervention; } \\
\text { lessessment at child and household } \\
\text { level (change in body mass index) }\end{array}$ & Awareness; behavior & Awareness; behavior \\
\hline
\end{tabular}

a Includes small, locally owned "mom-and-pop" establishments that include but are not limited to take-out and sit-down restaurants and restaurants that focused on specialty foods; it excludes chain restaurants.

b Feasibility assessment measures include acceptability, operability, and perceived sustainability.

c Process evaluation measures include dose, reach, and fidelity, which indicate how well the program was implemented according to plan.

d Consumer impact measures included psychosocial, behavioral, and health outcomes.

Table 2d. Evaluation Methods Used by Interventions on Prepared-Food Sources, by Type of Intervention: Interventions Conducted in Mixed Types of Restaurants a

\begin{tabular}{|l|l|l|l|}
\hline Characteristic & $\begin{array}{l}\text { Healthy Howard Initiative } \\
\text { (43) }\end{array}$ & \multicolumn{1}{|c|}{$\begin{array}{c}\text { Healthy Restaurant } \\
\text { Program (44-46) }\end{array}$} & $\begin{array}{c}\text { Winners Circle Healthy Dining } \\
\text { Program (47-49) }\end{array}$ \\
\hline Study design & $\begin{array}{l}\text { Nonexperimental design; } \\
\text { intervention trial, voluntary } \\
\text { participation; no comparison } \\
\text { group }\end{array}$ & $\begin{array}{l}\text { Nonexperimental design; pre- } \\
\text { post assessment; intervention } \\
\text { trial, voluntary participation; } \\
\text { no comparison group }\end{array}$ & $\begin{array}{l}\text { Nonexperimental; intervention trial, } \\
\text { voluntary participation; cross- } \\
\text { sectional survey of community } \\
\text { awareness of program; no } \\
\text { comparison group }\end{array}$ \\
\hline $\begin{array}{l}\text { Feasibility } \\
\text { assessment } \\
\text { measuresb }\end{array}$ & $\begin{array}{l}\text { Restaurant owner or } \\
\text { manager survey; focus } \\
\text { group; recipe analysis }\end{array}$ & $\begin{array}{l}\text { Interviews with chefs; survey } \\
\text { of restaurant managers or } \\
\text { staff }\end{array}$ & Survey of managers \\
\hline $\begin{array}{l}\text { Process } \\
\text { evaluation } \\
\text { measuresc }\end{array}$ & $\begin{array}{l}\text { Informal observation, } \\
\text { telephone communication; } \\
\text { annual health inspection; } \\
\text { recertification every 2 years }\end{array}$ & $\begin{array}{l}\text { Annual menu analysis; annual } \\
\text { observation }\end{array}$ & $\begin{array}{l}\text { Tracked reach and dose using } \\
\text { Winner's Circle team reporting } \\
\text { forms; menu review }\end{array}$ \\
\hline $\begin{array}{l}\text { Prepared-food } \\
\text { source impact } \\
\text { measures }\end{array}$ & $\begin{array}{l}\text { Restaurant owner or } \\
\text { manager survey (recall of } \\
\text { sales) }\end{array}$ & Restaurant owner survey & None \\
\hline $\begin{array}{l}\text { Consumer impact } \\
\text { measuresd }\end{array}$ & $\begin{array}{l}\text { Psychosocial, behavioral } \\
\text { survey }\end{array}$ & Awareness; attitudes & Awareness \\
\hline
\end{tabular}

a Includes restaurants (both local and chain) that did not share characteristics with other intervention restaurants or whose characteristics were not well defined.

b Feasibility assessment measures include acceptability, operability, and perceived sustainability.

c Process evaluation measures include dose, reach, and fidelity, which indicate how well the program was implemented 
Table 3a. Feasibility, Process, and Impact Results of Interventions on Prepared-Food Sources: Interventions Conducted in Specialty Restaurantsa

\begin{tabular}{|c|c|c|c|c|}
\hline Characteristic & $\begin{array}{l}\text { Baltimore Healthy } \\
\text { Carryouts (15-23) }\end{array}$ & $\begin{array}{l}\text { Good for You } \\
\text { (24) }\end{array}$ & $\begin{array}{l}\text { Steps to a Healthier } \\
\text { Salinas }(25,26)\end{array}$ & $\begin{array}{c}\text { Horgen and } \\
\text { Brownell } 2002 \\
(27)\end{array}$ \\
\hline $\begin{array}{l}\text { Feasibility and } \\
\text { process results }\end{array}$ & $\begin{array}{l}\text { High acceptability and fidelity } \\
\text { for Phase } 1 \text { and Phase } 3 ; \\
\text { medium acceptability and } \\
\text { operability for Phase } 2 ; \text { high } \\
\text { dose received }\end{array}$ & Not assessed & $\begin{array}{l}\text { Medium feasibility; } \\
\text { medium reach to owners; } \\
\text { moderate to high fidelity } \\
\text { in terms of changes to } \\
\text { menu items }\end{array}$ & $\begin{array}{l}\text { Assessed but } \\
\text { results not } \\
\text { reported }\end{array}$ \\
\hline $\begin{array}{l}\text { Prepared-food } \\
\text { source impact } \\
\text { results }\end{array}$ & $\begin{array}{l}\text { Increase in sales of promoted } \\
\text { items }\end{array}$ & $\begin{array}{l}\text { Increase in sales } \\
\text { of promoted items }\end{array}$ & Not assessed & $\begin{array}{l}\text { Increase in sales } \\
\text { of promoted } \\
\text { items, especially } \\
\text { with price } \\
\text { reductions }\end{array}$ \\
\hline $\begin{array}{l}\text { Consumer } \\
\text { psychosocial } \\
\text { impact results }\end{array}$ & Not assessed & Not assessed & $\begin{array}{l}\text { Assessed but results not } \\
\text { reported }\end{array}$ & $\begin{array}{l}\text { Assessed but } \\
\text { results not } \\
\text { reported because } \\
\text { of low response } \\
\text { rate }\end{array}$ \\
\hline $\begin{array}{l}\text { Consumer } \\
\text { behavioral } \\
\text { impact results }\end{array}$ & Increased purchasing & Not assessed & Not assessed & Not assessed \\
\hline Other results & $\begin{array}{l}\text { Community members' positive } \\
\text { response toward the } \\
\text { intervention }\end{array}$ & $\begin{array}{l}\text { Seasonality of } \\
\text { sales of some } \\
\text { foods (salad, } \\
\text { frozen yogurt) }\end{array}$ & $\begin{array}{l}\text { Mistrust of health } \\
\text { educators by restaurant } \\
\text { owners }\end{array}$ & $\begin{array}{l}\text { Health messages } \\
\text { not very effective }\end{array}$ \\
\hline Sustainability & Low implementation cost & $\begin{array}{l}\text { Sales of labeled } \\
\text { foods remained } \\
\text { high }\end{array}$ & $\begin{array}{l}\text { High sustainability: most } \\
\text { signage still displayed } 4 \\
\text { years later }\end{array}$ & $\begin{array}{l}\text { Went out of } \\
\text { business }\end{array}$ \\
\hline $\begin{array}{l}\text { Policy results, } \\
\text { implications }\end{array}$ & $\begin{array}{l}\text { Disseminated citywide as a } \\
\text { public market carryout } \\
\text { strategy "Get Fresh Public } \\
\text { Markets" }\end{array}$ & $\begin{array}{l}\text { Supports } \\
\text { effectiveness of } \\
\text { menu labeling }\end{array}$ & $\begin{array}{l}\text { Considering permits based } \\
\text { on healthful food offerings }\end{array}$ & $\begin{array}{l}\text { Subsidies on } \\
\text { healthful foods } \\
\text { can increase sales }\end{array}$ \\
\hline
\end{tabular}

a Includes restaurants, such as carryouts, taquerias, and delicatessen cafés, that focused on specialty foods; it excludes chain fast-food restaurants.

Table 3 b. Feasibility, Process, and Impact Results of Interventions on Prepared-Food Sources: Interventions Conducted in Chain Restaurants

\begin{tabular}{|c|c|c|c|}
\hline Characteristic & Coeur en Santé St-Henri $(28,29)$ & $\begin{array}{l}\text { TrEAT Yourself Well } \\
(\mathbf{3 0})\end{array}$ & $\begin{array}{c}\text { Tandon et al } 2011 \\
(31)\end{array}$ \\
\hline $\begin{array}{l}\text { Feasibility and } \\
\text { process results }\end{array}$ & $\begin{array}{l}\text { High acceptability among owners and } \\
\text { customers }\end{array}$ & Not assessed & None \\
\hline $\begin{array}{l}\text { Prepared-food } \\
\text { source impact } \\
\text { results }\end{array}$ & Not assessed & Not assessed & None \\
\hline $\begin{array}{l}\text { Consumer } \\
\text { psychosocial } \\
\text { impact results }\end{array}$ & $\begin{array}{l}\text { Awareness of campaign; intentions to eat } \\
\text { healthier }\end{array}$ & $\begin{array}{l}\text { High awareness; beliefs } \\
\text { about healthful food }\end{array}$ & $\begin{array}{l}\text { High awareness of } \\
\text { nutrition information }\end{array}$ \\
\hline
\end{tabular}




\begin{tabular}{|c|c|c|c|}
\hline Characteristic & Coeur en Santé St-Henri $(28,29)$ & $\begin{array}{l}\text { TrEAT Yourself Well } \\
(\mathbf{3 0})\end{array}$ & $\begin{array}{c}\text { Tandon et al } 2011 \\
\text { (31) }\end{array}$ \\
\hline $\begin{array}{l}\text { Consumer } \\
\text { behavioral impact } \\
\text { results }\end{array}$ & $\begin{array}{l}\text { Increased purchasing in family-style } \\
\text { restaurant compared with fast-food } \\
\text { restaurant }\end{array}$ & $\begin{array}{l}\text { Increased purchasing of } \\
\text { healthful foods }\end{array}$ & $\begin{array}{l}\text { No difference in mean } \\
\text { calories consumed } \\
\text { between or within } \\
\text { groups }\end{array}$ \\
\hline Other results & $\begin{array}{l}25 \% \text { of customers reported that they eat at } \\
\text { the restaurant at least once a week; health } \\
\text { and taste top } 2 \text { reasons for selecting } \\
\text { healthful items }\end{array}$ & $\begin{array}{l}\text { Demographic variables } \\
\text { had no effect on } \\
\text { awareness }\end{array}$ & No information \\
\hline Sustainability & $\begin{array}{l}\text { Permanent implementation of some } \\
\text { healthful foods }\end{array}$ & No information & No information \\
\hline $\begin{array}{l}\text { Policy results and } \\
\text { implications }\end{array}$ & $\begin{array}{l}\text { Evidence for feasibility of intervention in low } \\
\text {-income setting }\end{array}$ & $\begin{array}{l}\text { Moderate support for } \\
\text { promotional campaigns as } \\
\text { intervention strategy }\end{array}$ & None \\
\hline
\end{tabular}

Table 3c. Feasibility, Process, and Impact Results of Interventions on Prepared-Food Sources: Interventions Conducted in Small Local Restaurantsa

\begin{tabular}{|c|c|c|c|}
\hline Characteristic & Shape Up Somerville (32-36) & $\begin{array}{c}\text { Smart Menu Program } \\
(37,38)\end{array}$ & $\begin{array}{c}\text { The Healthy } \\
\text { Options Program } \\
\text { (39-42) }\end{array}$ \\
\hline $\begin{array}{l}\text { Feasibility and } \\
\text { process results }\end{array}$ & Low acceptability; medium reach & $\begin{array}{l}\text { High acceptability; low } \\
\text { feasibility; low reach; low } \\
\text { operability }\end{array}$ & $\begin{array}{l}\text { Moderate } \\
\text { acceptability of } \\
\text { promoted items; } \\
\text { high fidelity; high } \\
\text { feasibility }\end{array}$ \\
\hline $\begin{array}{l}\text { Prepared-food } \\
\text { source impact } \\
\text { results }\end{array}$ & $\begin{array}{l}4 / 10 \text { Restaurants changed menus; } 6 / 10 \\
\text { reported customers ordering from Shape Up } \\
\text { Somerville options; } 7 / 10 \text { believed beneficial to } \\
\text { participate; } 7 / 10 \text { were more aware of } \\
\text { nutrition; } 4 / 10 \text { thought customers were more } \\
\text { aware of nutrition }\end{array}$ & $\begin{array}{l}\text { Fewer average calories, } \\
\text { lower levels of fat and } \\
\text { sodium per entrée sold }\end{array}$ & $\begin{array}{l}\text { No significant change } \\
\text { in ordering }\end{array}$ \\
\hline $\begin{array}{l}\text { Consumer } \\
\text { psychosocial } \\
\text { impact results }\end{array}$ & Not assessed at restaurant level & $\begin{array}{l}\text { High level of awareness; no } \\
\text { impact on knowledge } \\
\text { reported }\end{array}$ & Moderate awareness \\
\hline $\begin{array}{l}\text { Consumer } \\
\text { behavioral } \\
\text { impact results }\end{array}$ & Not assessed at restaurant level & $\begin{array}{l}20.4 \% \text { of customers } \\
\text { reported ordering lower } \\
\text { calories, } 16.5 \% \text { lower fat }\end{array}$ & $\begin{array}{l}1 / 3 \text { of customers } \\
\text { reported materials } \\
\text { influenced ordering }\end{array}$ \\
\hline Other results & $\begin{array}{l}\text { Body mass index among children reduced by } \\
0.1005\end{array}$ & $\begin{array}{l}\text { Higher entrée cost } \\
\text { associated with more } \\
\text { calories and fat consumed; } \\
\text { consumers chose smaller, } \\
\text { cheaper entrées }\end{array}$ & None \\
\hline Sustainability & $\begin{array}{l}\text { Low-medium: more than } 50 \% \text { of restaurants } \\
\text { were noncompliant at follow-up }\end{array}$ & $\begin{array}{l}\text { Medium: resource-intensive } \\
\text { intervention. }\end{array}$ & $\begin{array}{l}\text { High: materials } \\
\text { stayed in place }\end{array}$ \\
\hline $\begin{array}{l}\text { Policy results, } \\
\text { implications }\end{array}$ & $\begin{array}{l}\text { Needed a stronger prepared-food source } \\
\text { component }\end{array}$ & $\begin{array}{l}\text { Success for calorie-labeling } \\
\text { policy }\end{array}$ & $\begin{array}{l}\text { Possibilities for } \\
\text { combination with } \\
\text { other intervention } \\
\text { strategies }\end{array}$ \\
\hline
\end{tabular}

a Includes small, locally owned "mom-and-pop" establishments that include but are not limited to take-out and sit-down restaurants and restaurants that focused on specialty foods; it excludes chain restaurants. 
Table 3d. Feasibility, Process, and Impact Results of Interventions on Prepared-Food Sources: Interventions Conducted in Mixed Types of Restaurantsa

\begin{tabular}{|c|c|c|c|}
\hline Characteristic & $\begin{array}{l}\text { Healthy Howard } \\
\text { Initiative (43) }\end{array}$ & $\begin{array}{c}\text { Healthy Restaurant Program (44- } \\
46 \text { ) }\end{array}$ & $\begin{array}{l}\text { Winners Circle Healthy } \\
\text { Dining Program (47-49) }\end{array}$ \\
\hline $\begin{array}{l}\text { Feasibility and process } \\
\text { results }\end{array}$ & $\begin{array}{l}\text { Moderate reach } \\
\text { (currently on-going) }\end{array}$ & $\begin{array}{l}\text { Increasing reach; improved ratings of } \\
\text { participating restaurants }\end{array}$ & $\begin{array}{l}\text { High feasibility; medium- } \\
\text { low reach }\end{array}$ \\
\hline $\begin{array}{l}\text { Prepared-food source } \\
\text { impact results }\end{array}$ & $\begin{array}{l}\text { Not assessed (surveys } \\
\text { not performed) }\end{array}$ & $\begin{array}{l}\text { Increase in sales of promoted items; } \\
\text { sodium and fat in foods significantly } \\
\text { decreased }\end{array}$ & Not assessed \\
\hline $\begin{array}{l}\text { Consumer } \\
\text { psychosocial impact } \\
\text { results }\end{array}$ & $\begin{array}{l}\text { Assessed but not } \\
\text { reported }\end{array}$ & High customer acceptability & Low awareness \\
\hline $\begin{array}{l}\text { Consumer behavioral } \\
\text { impact results }\end{array}$ & $\begin{array}{l}\text { Assessed but not } \\
\text { reported }\end{array}$ & Not assessed & $\begin{array}{l}\text { Medium use of label for } \\
\text { food choice }\end{array}$ \\
\hline Other results & None & None & None \\
\hline Sustainability & $\begin{array}{l}\text { Low implementation } \\
\text { cost }\end{array}$ & $\begin{array}{l}\text { High: } 85 / 96 \text { of restaurants are } \\
\text { maintaining program }\end{array}$ & $\begin{array}{l}\text { Low-cost, easily } \\
\text { implemented }\end{array}$ \\
\hline $\begin{array}{l}\text { Policy results, } \\
\text { implications }\end{array}$ & Voluntary program & $\begin{array}{l}\text { Ordinance for the Healthy Restaurant } \\
\text { Program }\end{array}$ & No links with policy \\
\hline
\end{tabular}

a Includes restaurants (both local and chain) that did not share characteristics with other intervention restaurants or whose characteristics were not well defined.

\section{Appendix. Adjudication Chart for Study Review}

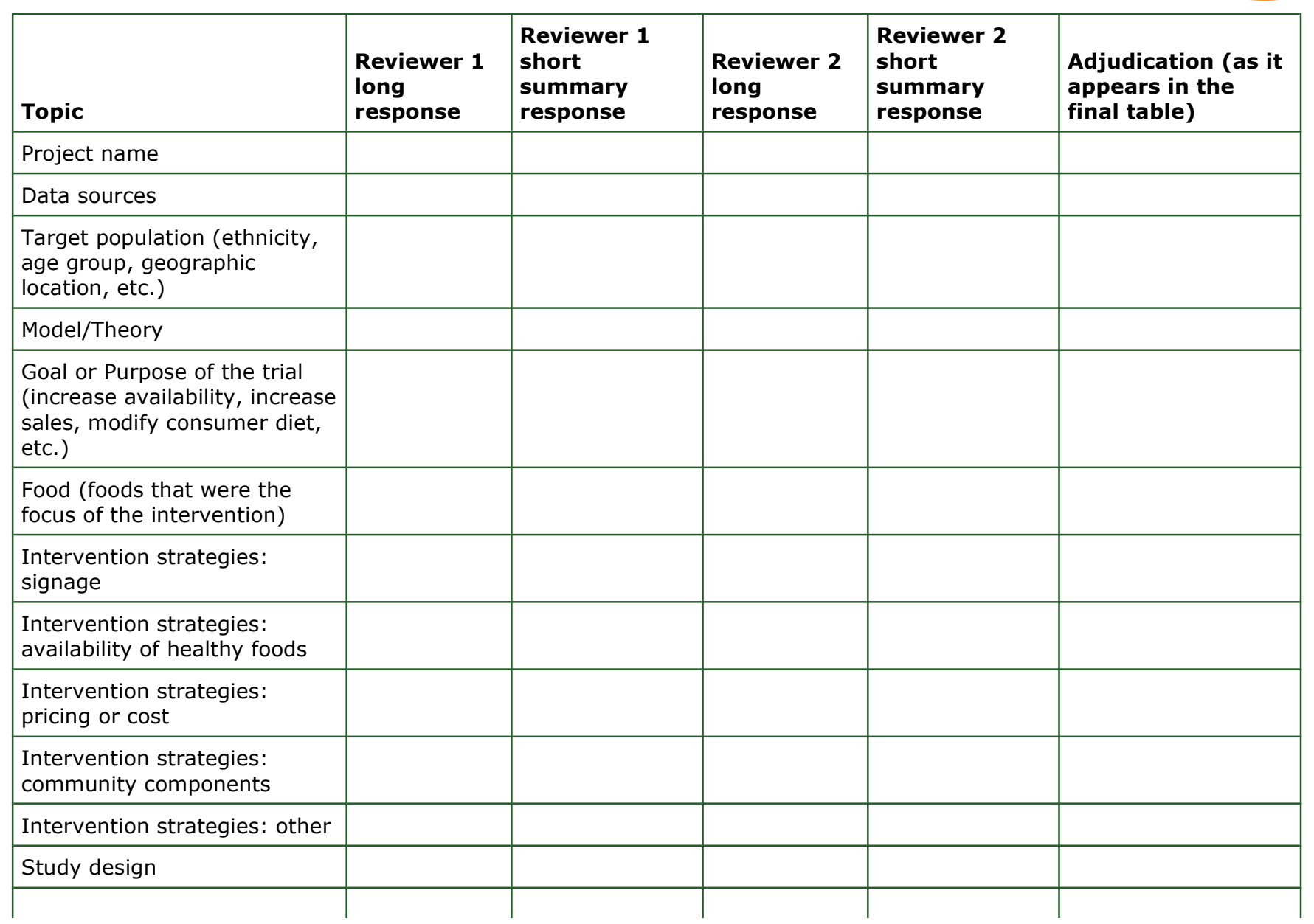




\begin{tabular}{|l|l|l|l|l|l|}
\hline & $\begin{array}{l}\text { Reviewer 1 } \\
\text { long } \\
\text { response }\end{array}$ & $\begin{array}{l}\text { Reviewer 1 } \\
\text { short } \\
\text { summary } \\
\text { response }\end{array}$ & $\begin{array}{l}\text { Reviewer 2 } \\
\text { long } \\
\text { response }\end{array}$ & $\begin{array}{l}\text { Reviewer 2 } \\
\text { short } \\
\text { summary } \\
\text { response }\end{array}$ & $\begin{array}{l}\text { Adjudication (as it } \\
\text { appears in the } \\
\text { final table) }\end{array}$ \\
\hline Formative research & & & & & \\
\hline $\begin{array}{l}\text { Feasibility assessment } \\
\text { (acceptability, operability, } \\
\text { perceived sustainability) }\end{array}$ & & & & & \\
\hline $\begin{array}{l}\text { Process evaluation (how well } \\
\text { the program was } \\
\text { implemented according to } \\
\text { plan) }\end{array}$ & & & & & \\
\hline $\begin{array}{l}\text { Prepared-food source impact } \\
\text { measures }\end{array}$ & & & & & \\
\hline $\begin{array}{l}\text { Consumer impact measures } \\
\text { (psychosocial, behavioral, } \\
\text { health outcomes) }\end{array}$ & & & & & \\
\hline Feasibility and process results & & & & & \\
\hline $\begin{array}{l}\text { Prepared-food source impact } \\
\text { results }\end{array}$ & & & & & \\
\hline $\begin{array}{l}\text { Consumer psychosocial } \\
\text { Impact results }\end{array}$ & & & & & \\
\hline $\begin{array}{l}\text { Consumer behavioral impact } \\
\text { results }\end{array}$ & & & & & \\
\hline Other results & & & & \\
\hline Sustainability & & & & \\
\hline Policy results, implications & & & & \\
\hline
\end{tabular}

The opinions expressed by authors contributing to this journal do not necessarily reflect the opinions of the U.S. Department of Health and Human Services, the Public Health Service, the Centers for Disease Control and Prevention, or the authors' affiliated institutions.

The RIS file format is a text file containing bibliographic citations. These files are best suited for import into bibliographic management applications such as EndNote圈, Reference Manager圈, and ProCite 圈. A free trial download is available at each application's web site.

For Questions About This Article Contact pcdeditor@cdc.gov

Page last reviewed: October 31, 2013

Page last updated: October 31, 2013

Content source: National Center for Chronic Disease Prevention and Health Promotion

Centers for Disease Control and Prevention 1600 Clifton Rd. Atlanta, GA 30333, USA

80o-CDC-INFO (800-232-4636) TTY: (888) 232-6348 - Contact CDC-INFO

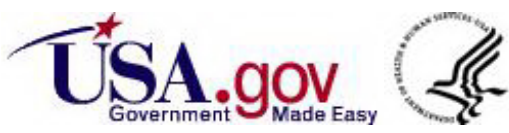

